\title{
PEMODELAN LOGIT, PROBIT, DAN COMPLEMENTARY LOG-LOG
}

\author{
Studi Kasus: Partisipasi Angkatan Kerja Perempuan dalam Perekonomian di \\ Kalimantan Timur Tahun 2019 \\ (Modeling Logit, Probit, and Complementary Log-Log Case Study: Women's Labor Force
}

Participation in the Economy in East Kalimantan 2019)

Dwi ayu setyaningrum ${ }^{1}$, Timbang Sirait ${ }^{2}$

Politeknik Statistika STIS ${ }^{1}$

Politeknik Statistika STIS ${ }^{2}$

Jl. Otto Iskandardinaa No. 64 C Jakarta 13330

E-mail: $\underline{16.9091 @ s t i s . a c . i d ~}$

\begin{abstract}
ABSTRAK
Pemodelan data yang tepat dapat digunakan dalam pengambilan keputusan yang bersifat strategis. Salah satu bentuk pemodelan yang umum digunakan yaitu analisis regresi. Dalam pemodelan regresi harus dilihat tipe data pada variabel respon terlebih dahulu agar dapat menentukan pemodelan yang dapat dilakukan sesuai tipe data. Tujuan dari penelitian ini adalah untuk mengetahui gambaran umum dan karakteristik partisipasi angkatan kerja perempuan dalam perekonomian di Kalimantan Timur (Kaltim) tahun 2019, melakukan pemodelan data dengan menggunakan regresi Logistik Biner, Probit Biner dan Complementary Log-log. Variabel respon yang digunakan dalam pemodelan adalah status kerja perempuan sedangkan variabel penjelas yaitu kepemilikan anak, status kawin, status kemiskinan, status KRT, tempat tinggal, dan tingkat pendidikan. Hasil Penelitian menunjukkan bahwa dengan nilai AIC diperoleh regresi Complementary log-log sebagai model terbaik karena memiliki nilai AIC terkecil dibandingkan dengan model logistik biner dan probit. Kecenderungan perempuan usia angkatan untuk berpartisipasi dalam perekonomian di Kaltim tahun 2019 lebih besar bagi perempuan yang memiliki balita, status belum menikah atau cerai mati, status ekonomi miskin, tidak sebagai kepala rumah tangga, bertempat tinggal diperkotaan, dan pendidikan kurang atau sama dengan SMA/Sederajat.
\end{abstract}

Kata kunci: logit biner, probit biner, complementary log-log, partisipasi perempuan dalam perekonomian

\section{ABSTRACT}

Appropriate data modeling can be used in strategic decision making. One form of modeling that is commonly used is regression analysis. In regression modeling, the data type on the response variable must be seen first in order to determine which modeling can be carried out according to the data type. The purpose of this study was to determine the general description and characteristics of women's labor force participation in the economy in East Kalimantan (Kaltim) in 2019, modeling data using Binary Logistic, Binary Probit and Complementary Log-log regression. The response variable used in the modeling is women's work status, while the explanatory variables are child ownership, marital status, poverty status, household head status, residence, and education level. The results showed that the AIC value obtained Complementary log-log regression as the 
best model because it has the smallest AIC value compared to the binary and probit logistic models. The tendency of women of age group to participate in the economy in Kaltim 2019 is greater for women who have children under five, are not married or divorced, have poor economic status, are not the head of household, live in cities, and have less or the same education as SMA / Equal.

Keywords: binary logit, binary probit, complementary log-log, women's participation in the economy

\section{PENDAHULUAN}

Pengaruh globalisasi menyebabkan banyaknya variasi data yang tersedia untuk saat ini. Data akan memiliki banyak manfaat jika diolah dan diartikan dengan baik. Pengetahuan tentang pengolahan data akan sangat bermanfaat bagi pengguna data yaitu membantu mengambil keputusan yang bersifat strategis terkait pengolahan dan implementasi yang akan dilakukan. Salah satu metode pengolahan data yang umum digunakan adalah metode analisis regresi. Menurut Agresti (2013), "Pada umumnya analisis statistik membedakan antara variabel respon (dependent) dan variabel penjelas (independent). Dengan tipe data yang berbeda, maka analisis regresi akan berbeda pula. Pada umumnya akan dilakukan pengkategorian data yang disebut dengan data kategorik. Data ketegorik digunakan untuk membedakan antara variabel respon dan variabel penjelas dimana menitikberatkan pada variabel respon yang bersifat kategorik, membedakan menurut skala pengukuran yang menitikberatkan pada variabel respon skala nominal atau ordinal, membedakan antara data diskrit atau kontinu dimana data kontinu yang telah dikategorikan, dan membedakan menurut kuantitatif dan kualitatif data" (hal. 2).

Analisis data kategorik dan data numerik dibedakan berdasarkan ukuran-ukuran statistik yang dapat digunakan dan berdasarkan distribusi probabilitas data. Pemodelan data kategorik lebih mudah digunakan karena asumsi yang harus terpenuhi lebih sederhana daripada pemodelan data numerik. Beberapa model data kategorik yang umum digunakan oleh penelitian adalah model logistik biner, probit, dan complemetary log-log. Salah satu contoh kasus data kategorik adalah status kerja, dimana terdapat dua kategori status kerja yaitu bekerja dan tidak bekerja.

Pertumbuhan penduduk yang tinggi akan berdampak positif pada suatu negara karena semakin banyaknya sumber daya manusia yang sangat besar. Namun pertumbuhan penduduk yang tinggi akan berdampak negatif jika tidak diimbangi dengan sarana-prasarana dalam pemenuhan kebutuhan masyarakat seperti lapangan pekerjaan. Pada tahun 2018, jumlah penduduk sebesar 264.16 juta jiwa, yang terdiri dari 132.68 juta jiwa penduduk laki-laki dan 131.47 juta jiwa penduduk perempuan. Selama ini pertumbuhan jumlah penduduk laki-laki selalu lebih banyak dibandingkan perempuan, namun hasil proyeksi jumlah penduduk pada tahun 2032 menunjukkan bahwa penduduk perempuan diperkirakan lebih banyak daripada laki-laki, yaitu perempuan sebanyak 149,19 juta jiwa sementara laki-laki berjumlah 149,17 juta jiwa. Hal tersebut menunjukkan bahwa jumlah penduduk perempuan lebih 21 ribu dibandingkan laki-laki. 
Berdasarkan hasil SUSENAS (2018) menunjukkan bahwa, mayoritas penduduk Indonesia merupakan penduduk berumur produktif. Dimana setiap 100 penduduk berumur produktif mempunyai tanggungan kurang lebih 48 penduduk yang belum produktif/ tidak produktif lagi. Angka tersebut cukup baik jika diasumsikan bahwa semua penduduk Indonesia usia produktif mempunyai pekerjaan. Namun faktanya, pada tahun 2019 masih terdapat 5.28 persen tingkat pengangguran terbuka (TPT), 8.13 juta orang yang setengah menganggur, dan 28.41 juta pekerja paruh waktu. Terkait hal itu maka akan menambah beban pada penduduk usia produktif.

Jumlah angkatan kerja pada tahun 2018 sebanyak 133.94 juta orang yang naik 2.39 juta orang dibandingkan tahun sebelumnya. Tingkat partisipasi angkatan kerja (TPAK) sebesar 69.20 persen yang meningkat 0.18 persen dari tahun sebelumnya. Kenaikan jumlah angkatan kerja juga sejalan dengan peningkatan jumlah penduduk. Meskipun tingkat partisipasi angkatan kerja naik, namun tingkat pengangguran terbuka masih cukup tinggi yaitu 5.13 persen. Berdasarkan jenis kelamin, TPAK laki-laki pada tahun 2018 sebesar 82.69 persen, sedangkan TPAK perempuan hanya 51.88 persen. Hal tersebut masih ada kesenjangan yang terjadi antara laki-laki dan perempuan di bidang ketenagakerjaan. Ada beberapa faktor yang mempengaruhi rendahnya nilai TPAK perempuan yaitu salah satunya masih terdapat budaya Indonesia yang menganut budaya patriarki. Menurut Rokhmansyah (2013) dibukunya yang berjudul Pengantar Gender dan feminisme, patriarki berasal dari kata partriakat yang artinya struktur menempatkan laki-laki sebagai penguasa tunggal, sentral, dan segala-galanya. Sistem tersebut dapat mempengaruhi kesenjangan dan ketidakadilan gender kedalam berbagai aspek. Misalnya dalam bidang pendidikan, pekerjaan, politik, dan lainnya yang masih rendah peran perempuan di dalamnya. Beberapa penelitian yang menggunakan kasus yang serupa yaitu penelitian Cahya (2015) mengenai pemodelan Logit, Probit, dan Complementary LogLog pada Studi Kasus Partisipasi Perempuan dalam Pembangunan Ekonomi di Kalimantan Selatan. Penelitian tersebut membandingkan anatara tiga model analisis dengan variabel respon status pekerjaan dan variabel penjelas yaitu pendidikan dan tempat tinggal, dilanjutkan dengan pemilihan model terbaik. Hasil penelitian menunjukkan bahwa tidak terlalu signifikan perbedaan model yang dibentuk. Sedangkan penelitian lain yaitu pemodelan regresi tobit oleh Inayah (2010) dengan judul Analisis Faktor-Faktor yang Mempengaruhi Partisipasi Perempuan dalam Perekonomian Rumah Tangga di Kota Semarang Menggunakan Regresi Tobit. Penelitian Chisti (2013) dengan judul Analisis Regresi Double Hurdle Terhadap Faktor-Faktor yang Mempengaruhi Partisipasi Perempuan Kawin dalam Kegiatan Ekonomi di Jawa Timur.

Berdasarkan uraian diatas, penulis ingin meneliti pemodelan logit, probit, dan complementary log-log pada partisipasi angkatan kerja perempuan dalam perekonomian di Kaltim tahun 2019. Tujuan dari penelitian ini adalah: (1) Menentukan gambaran umum dan karakteristik partisipasi perempuan usia angkatan kerja di Kaltim tahun 2019. (2) Pemodelan beberapa metode untuk menentukan model terbaik dari faktor-faktor yang mempengaruhi partisipasi perempuan usia 
angkatan kerja di Kaltim tahun 2019. (3) Pemodelan terbaik digunakan untuk mengetahui seberapa besar pengaruh variabel-variabel penjelas terhadap variabel respons pada kasus partisipasi perempuan usia angkatan kerja di Kaltim tahun 2019.

\section{METODE}

Analisis deskriptif digunakan untuk mendeskripsikan atau menggambarkan data secara umum (Sugiyono, 2008: 147). Dalam penelitian ini analisis deskriptif bertujuan untuk melihat karakteristik variabel-variabel penjelas meliputi pendidikan, status perkawinan, tempat tinggal, status kemiskinan, dan status keanggotaan dalam rumah tangga diduga mempengaruhi tingkat partisipasi perempuan dalam perekonomian di Kaltim tahun 2019.

Analisis Inferensia pada penelitiian ini terdiri dari beberapa model regresi yaitu:

\section{Regresi Logistik Biner}

Regresi logistik biner adalah suatu metode analisis data yang digunakan untuk mencari hubungan antara variabel respon yang bersifat dikotomus dengan variabel penjelas yang bersifat dikotomus atau polikotomus. Variabel respon terdiri dari dua kategori yaitu "sukses" dan "gagal" sehingga distribusi yang diikuti adalah distribusi Bernoulli untuk setiap observasi tunggal. Fungsi probabilitas regresi logistik dinotasikan $\mathrm{P}(\mathrm{Y}=1 \mid \mathrm{X})=\mathrm{p}$. Transformasi dari model regresi logistik sebagai berikut:

$$
\pi(x)=\frac{\exp \left(\beta_{0}+\beta_{1} x_{1}+\beta_{2} x_{2}+\cdots+\beta_{p} x_{p}\right)}{1+\exp \left(\beta_{0}+\beta_{1} x_{1}+\beta_{2} x_{2}+\cdots+\beta_{p} x_{p}\right)}
$$

Sehingga model logistik yang terbentuk adalah sebagai berikut:

$$
g(x)=\beta_{0}+\beta_{1} x_{1}+\beta_{2} x_{2}+\cdots+\beta_{p} x_{p}
$$

dimana:

$$
\begin{array}{ll}
\pi(x) & =\text { peluang kejadian sukses } \\
\mathrm{p} & =\text { jumlah variabel bebas } \\
\mathrm{x} & =\text { koefisien } \mathrm{x} \\
\beta_{p} & =\text { nilai koefisien } \mathrm{x} \text { pada variabel ke } \mathrm{p} \\
g(x) & =\text { nilai } \mathrm{y}
\end{array}
$$

\section{Regresi Probit Biner}

Regresi probit adalah suatu metode analisis data yang digunakan untuk menjelaskan pola hubungan antara variabel respon yang bersifat dikotomus yang dikategorikan berdasarkan threshold 
tertentu dengan variabel penjelas. Distribusi yang diikuti adalah distribusi normal dengan fungsi probabilitas sebagai berikut:

Penulisan rumus dalam Bab Metode adalah sebagai berikut:

$$
\pi(x)=F^{-1}\left(I_{i}\right)=F^{-1}\left(\beta_{0}+\beta_{i} X_{i}\right)
$$

dimana:

$\pi(x)=$ peluang kejadian sukses

$\mathrm{p} \quad=$ variabel bebas ke- $\mathrm{i}$

$\mathrm{x} \quad=$ koefisien $\mathrm{x}$

$\beta_{p} \quad=$ nilai koefisien $\mathrm{x}$ pada variabel ke $\mathrm{p}$

$F^{-1}\left(I_{i}\right)=$ probability density function (PDF)

\section{Regresi Complementary Log- Log}

Regresi complementary log-log adalah suatu metode analisis data yang digunakan untuk menjelaskan hubungan antara variabel respon yang bersifat dikotomus yang dikategorikan berdasarkan threshold tertentu dengan variabel penjelas. Distribusi yang diikuti adalah distribusi gompertz dengan fungsi probabilitas sebagai berikut:

$$
\pi\left(x_{i}\right)=1-\exp \left[-\exp \left(\beta_{0}+\sum_{i=1}^{p} \beta_{i} x_{i}\right)\right]
$$

dimana:

$\pi(x)=$ peluang kejadian sukses

$\mathrm{p}=$ variabel bebas ke-i

$\mathrm{x} \quad=$ koefisien $\mathrm{x}$

$\beta_{p} \quad=$ nilai koefisien $\mathrm{x}$ pada variabel ke $\mathrm{p}$

Software yang digunakan dalam proses pengolahan data adalah R studio 4.0.2, Microsoft Excel 2013, serta Gephi 0.9.2. R studio digunakan dalam proses pengambilan dan pembersihan data tweet, pembuatan wordcloud, serta analisis sentimen. Sedangkan Gephi digunakan untuk melakukan Social Network Analysis (SNA).

HASIL DAN PEMBAHASAN

Gambaran umum Karakteristik Partisisapasi Perempuan Usia Angkatan Kerja Dalam Perekonomian di Kaltim 2019 
Pada penelitian ini digunakan data hasil Susenas 2019 pada bulan Maret yang dilaksanakan oleh BPS. Sampel yang digunakan dalam penelitian ini sebanyak 7066 perempuan usia kerja di Kaltim tahun 2019, dimana sebanyak 3895 berstatus kerja sedangkan sebanyak 3171 berstatus tidak bekerja. Tingkat partisipasi perempuan dalam perekonomian erat kaitannya dengan keadaan sosialekonomi. Karakteristik perempuan usia kerja di Kaltim akan disajikan dalam bentuk ringkasan tabel, selanjutnya mengenai gambaran hubungan antar variabel respon dengan variable-variabel penjelas akan disusun berdasarkan masing-masing variabel dalam bentuk diagram batang dan lingkaran.

Variabel yang akan dijelaskan adalah variabel respon (status kerja perempuan) dan lima variabel penjelas yaitu kepemilikan balita, status perkawinan, status kemiskinan, status KRT, tempat tinggal, dan tingkat pendidikan.

Tabel 1. Frekuensi dan persentase gambaran umum karakteristik partisipasi Angkatan kerja perempuan dalam pereknomian di Kaltim Tahun 2019.

\begin{tabular}{|c|c|c|c|}
\hline & Nama Variabel & Frekuensi (n) & Persentase (\%) \\
\hline \multirow[t]{3}{*}{1.} & Status Pekerja & & \\
\hline & Tidak Bekerja & 3171 & 44.88 \\
\hline & Bekerja & 3895 & 55.12 \\
\hline \multirow[t]{3}{*}{2.} & Kepemilikan Balita & & \\
\hline & Tidak Ada Balita & 4745 & 67.15 \\
\hline & Ada Balita & 2321 & 32.85 \\
\hline \multirow[t]{3}{*}{3.} & Status Kawin & & \\
\hline & Kawin & 5188 & 73.42 \\
\hline & Tidak Kawin & 1878 & 26.58 \\
\hline \multirow[t]{3}{*}{4.} & Status Kemiskinan & & \\
\hline & Tidak Miskin & 6664 & 94.31 \\
\hline & Miskin & 402 & 5.69 \\
\hline \multirow[t]{3}{*}{5.} & Status KRT & & \\
\hline & KRT & 570 & 8.07 \\
\hline & Tidak KRT & 6496 & 91.93 \\
\hline \multirow[t]{3}{*}{6.} & Tempat Tinggal & & \\
\hline & Perdesaan & 2895 & 40.97 \\
\hline & Perkotaan & 4171 & 59.03 \\
\hline \multirow[t]{3}{*}{7.} & Tingkat Pendidikan & & \\
\hline & Perguruan Tinggi & 958 & 13.56 \\
\hline & $\leq \mathrm{SMA} / \mathrm{SMK} /$ Sederajat & 6108 & 86.44 \\
\hline
\end{tabular}

Sumber: data Susenas 2019 (diolah)

Pemodelan Data Menggunakan Beberapa Model Estimasi Parameter 
Untuk mengetahui bagaimana pengaruh antara variabel status kerja dengan beberapa variabel penjelasnya dilakukan pemodelan logit, probit, dan complementary log-log. Berikut ini estimasi parameter dapat dilihat dari nilai $R$. pada setiap pemodelan. Pada setiap nilai estimasi parameter disetiap model menghasilkan tanda pengaruh yang sama.

Tabel 2. Pemodelan data partisipasi Angkatan kerja perempuan dalam perekonomian di Kaltim tahun 2019

\begin{tabular}{lccccccc}
\hline \multirow{2}{*}{ Pemodelan } & \multicolumn{7}{c}{ Koefisien } \\
\cline { 2 - 7 } & konstanta & $\begin{array}{c}\text { Kepemilikan } \\
\text { Balita }\end{array}$ & $\begin{array}{c}\text { Status } \\
\text { Kawin }\end{array}$ & $\begin{array}{c}\text { Status } \\
\text { Kemiskinan }\end{array}$ & $\begin{array}{c}\text { Status } \\
\text { KRT }\end{array}$ & $\begin{array}{c}\text { Tempat } \\
\text { Tinggal }\end{array}$ & Pendidikan \\
\hline Logit & -2.425 & 0.271 & 0.676 & 0.368 & 1.427 & 0.126 & 1.108 \\
Probit & -1.478 & 0.164 & 0.413 & 0.226 & 0.870 & 0.075 & 0.679 \\
Complementary & -2.138 & 0.175 & 0.437 & 0.217 & 1.038 & 0.067 & 0.825 \\
Log-log & & & & & & & \\
\hline
\end{tabular}

Sumber: data Susenas 2019 (diolah)

\section{Uji Signifikasi Parameter dan Pemilihan Model Terbaik}

Pengujian signifikasi secara parsial dilakukan untuk mengetahui apakah variabel-variabel penjelas secara signifikan memengaruhi variabel respons yaitu status kerja pada perempuan usia angkatan kerja di Kaltim tahun 2019. Pada pengujian parsial dilakukan dengan nilai statistik uji Wald (W) yang dibandingkan dengan nilai chi-square tabel, atau dengan melihat nilai p-value yang dihasilkan.

Pengujian secara simultan dilakukan dengan tujuan untuk mengetahui apakah variabel penjelas secara bersama-sama (simultan) berpengaruh pada model pertisipasi angkatan kerja perempuan dalam perekonomian di Kaltim tahun 2019. Pengujian secara simultan dilakukan dengan nilai statistik uji G. Pemilihan model terbaik berdasarkan nilai AIC yang terkecil.

Berikut ini disajikan data nilai statistik uji Wald, uji G, dan nilai AIC pada setiap model.

Tabel 3. Uji Signifikan parsial, simultan parameter dan nilai AC pada pemodelan data partsipasi angkata kerja perempuan dalam perekonomian di Kaltim tahun 2019

\begin{tabular}{ccccc}
\hline \multirow{2}{*}{ Koefisien } & \multicolumn{3}{c}{ Pemodelan } \\
\cline { 3 - 5 } & & Logit & Probit & Complementary Log-log \\
\cline { 3 - 5 } & Wald & -2.425 & -18.890 & -20.889 \\
& P & 0.000 & 0.000 & 0.000
\end{tabular}




\begin{tabular}{ccccc}
$\boldsymbol{\beta}_{\mathbf{1}}$ & Wald & 4.989 & 4.928 & 4.890 \\
$\boldsymbol{\beta}_{\mathbf{2}}$ & P-value & 0.000 & 0.000 & 0.000 \\
& Wald & 10.965 & 11.090 & 11.435 \\
$\boldsymbol{\beta}_{\mathbf{3}}$ & p-value & 0.000 & 0.000 & 0.000 \\
& Wald & 3.256 & 3.295 & 3.171 \\
$\boldsymbol{\beta}_{\mathbf{4}}$ & p-value & 0.001 & 0.001 & 0.002 \\
& Wald & 13.988 & 14.243 & 12.830 \\
$\boldsymbol{\beta}_{\mathbf{5}}$ & p-value & 0.000 & 0.000 & 0.000 \\
& Wald & 2.478 & 2.396 & 1.968 \\
\multirow{2}{*}{$\boldsymbol{\beta}_{\mathbf{6}}$} & p-value & 0.013 & 0.017 & 0.049 \\
& Wald & 14.635 & 14.781 & 13.662 \\
& p-value & 0.000 & 0.000 & 0.000 \\
\hline Uji Wald & Chi-Square & 12.816 & 13.616 & 14.465 \\
& p-value & 0.118 & 0.092 & 0.070 \\
\hline AIC & - & 9182.9 & 9184.9 & 9181.1 \\
\hline
\end{tabular}

Sumber: data Susenas 2019 (diolah)

\section{Variabel-Variabel yang Memengaruhi Partisipasi Angkatan Kerja Perempuan dalam Perekonomian di Kaltim 2019}

Pada penelitian ini telah dipaparkan beberapa karakteristik perempuan usia angkatan kerja yang berpengaruh dalam status kerja perempuan di Kaltim. Terkait beberapa pemodelan data yang sudah dilakukan, diperoleh pemodelan regresi Complementary Log-log yang merupakan model terbaik pada kasus partisipasi angkatan kerja perempuan dalam perekonomian di Kaltim pada tahun 2019.

Dengan demikian, untuk analisis inferensia lebih lanjut terkait variabel-variabel yang mempengaruhi partisipasi angkatan kerja perempuan dalam perekonomian di Kaltim tahun 2019 akan menggunakan model regresi nonlinear fungsi penghubung Complementary log-log. Berikut ini merupakan persamaan yang diperoleh:

$$
\begin{aligned}
\hat{\pi}=1-\exp ( & -\exp \left(-2.138+0.175 x_{1}+0.437 x_{2}+0.217 x_{3}+1.038 x_{4}+0.067 x_{5}\right. \\
& +0.825 x_{6}
\end{aligned}
$$

Bentuk persamaan diatas merupakan bentuk persamaan nonlinier, sehingga diperlukan transformasi ke dalam bentuk Complementary log-log. Berikut ini adalah bentuk persamaan yang sudah ditransformasikan:

$$
\hat{g}(x)=-2.138+0.175 x_{1}+0.437 x_{2}+0.217 x_{3}+1.038 x_{4}+0.067 x_{5}+0.825 x_{6}
$$


Pada persamaan diatas dapat ditunjukkan bahwa pada koefisien regresi variabel kepemilikan jumlah balita bertanda negatif yang artinya, ketika seorang perempuan usia angkatan kerja tidak memiliki tanggungan balita maka peluang untuk dia berstatus kerja semakin kecil dibandingkan dengan yang memiliki tanggungan balita. Koefisien pada variabel status kawin bertanda negatif, artinya ketika seorang perempuan usia angkatan kerja berstatus kawin (kawin atau cerai hidup) maka peluang untuk berstatus kerja akan semakin kecil jika dibandingkan dengan perempuan yang tidak kawin (belum kawin, cerai mati).

Pada koefisien variabel status kemiskinan bertanda positif, artinya perempuan usia angkatan kerja yang miskin memiliki peluang untuk bekerja semakin besar dibandingkan dengan penduduk tidak miskin. Begitupula pada koefisien status kepala rumah tangga, dimana penduduk perempuan yang berstatus tidak menjadi kepala rumah tangga memiliki peluang untuk bekerja semakin besar. Pada variabel tempat tinggal bertanda negatif, artinya penduduk yang tinggal diperdesaan akan memiliki peluang untuk bekerja semakin kecil jika dibandingkan dengan penduduk yang tinggal di perkotaan. Pada variabel tingkat pendidikan, dimana perempuan usia angkatan kerja yang tamatan pendidikan dibawah atau sama dengan SMA akan memperbesar peluang untuk bekerja dibandingkan perempuan dengan pendidikan perguruan tinggi.

\section{Resiko Variabel yang mempengaruhi status kerja perempuan usia angkatan kerja di Kaltim tahun 2019}

Nilai resiko variabel diperoleh dengan eksponensial pada nilai koefisien pada setiap variabel penjelas, sehingga diperoleh bahwa nilai untuk variabel kepemilikan balita adalah sebesar 0.839 , artinya perempuan usia angkatan kerja di Kaltim yang tidak ada balita memiliki resiko untuk berstatus kerja 0.893 kali dibandingkan dengan perempuan usia Angkatan kerja yang memiliki balita. Nilai untuk variabel status kawin adalah sebesar 0.646 , artinya perempuan usia angkatan kerja di Kaltim yang kawin atau cerai hidup memiliki resiko untuk kerja sebesar 0.646 kali dibandingkan dengan perempuan usia angkatan kerja yang belum kawin atau cerai mati. Nilai untuk variabel status kemiskinan adalah sebesar 1.243 , artinya perempuan usia angkatan kerja di Kaltim yang miskin memiliki resiko untuk kerja sebesar 1.243 kali lebih besar dibandingkan dengan perempuan usia angkatan kerja yang tidak miskin di Kaltim. Nilai untuk variabel status KRT adalah sebesar 2.824, artinya perempuan usia angkatan kerja di Kaltim yang tidak menjadi KRT memiliki resiko untuk bekerja sebesar 2.824 kali lebih besar dibandingkan dengan perempuan usia angkatan kerja yang memiliki menjadi KRT. Nilai untuk variabel tempat tinggal adalah sebesar 0.935 , artinya perempuan usia angkatan kerja di Kaltim yang tinggal di perdesaan memiliki resiko untuk bekerja sebesar 0.935 kali dibandingkan dengan perempuan usia angkatan kerja yang tinggal di perkotaan. Nilai untuk variabel tingkat pendidikan adalah sebesar 2.281, artinya perempuan usia angkatan kerja di Kaltim 
yang berpendidikan sama atau kurang dari SMA memiliki resiko untuk bekerja sebesar 2.381 kali dibandingkan dengan perempuan usia angkatan kerja yang berpendidikan perguruan tinggi.

\section{KESIMPULAN}

Dari pemaparan hasil penelitian, dapat ditarik kesimpulan bahwa secara umum, persentase penduduk perempuan usia angkatan kerja yang bekerja adalah 44.88 persen dan 55.12 persen tidak bekerja. persentase status kerja lebih besar untuk perempuan usia angkatan kerja yang memiliki balita, berstatus tidak kawin, berada pada perekonomian miskin, berstatus tidak sebagai KRT, bertempat tinggal di perkotaan, dan tingkat pendidikannya yaitu kurang atau sama dengan SMA/sederajat.

Pada pemodelan regresi logistik, regresi probit, dan regresi complementary log-log menunjukkan bahwa pada masing-masing model semua variabel berpengaruh signifikan secara bersama-sama terhadap variabel penjelas. Semua model memiliki koefisien yang signifikan pada uji signifikansi parsial, dan pada uji kesesuaian model. Sedangkan untuk pemilihan model terbaik dengan nilai AIC diperoleh regresi Complementary log-log sebagai model terbaik karena memiliki nilai AIC terkecil dibandingkan dengan model lainnya.

Variabel-variabel yang signifikan mempengaruhi partisipasi perempuan dalam perekonomian di Kaltim tahun 2019 adalah variabel kepemilikan balita, status kawin, status kemiskinan, status KRT, tempat tinggal, dan tingkat pendidikan. Kecenderungan perempuan usia angkatan untuk berpartisipasi dalam perekonomian di Kaltim tahun 2019 lebih besar bagi perempuan yang memiliki balita, status belum menikah atau cerai mati, status ekonomi miskin, tidak sebagai kepala rumah tangga, bertempat tinggal diperkotaan, dan pendidikan kurang atau sama dengan SMA/SMA/Sederajat.

\section{DAFTAR PUSTAKA}

Adioetomo, S.M.S. (2003). Bonus Demografi: menjelaskan hubungan antara pertumbuhan penduduk dengan pertumbuhan ekonomi. Jakarta : Universitas Indonesia.

Agresti, Allan. (2002). Categorical Data Analysis ( $2^{\text {nd }}$ ed). New York: John Wiley \& Sons. Inc.

Azen, Razia., \& Walker, C.M. (2011). Categorical Data Analysis for the Behavioral and Social Sciences. New York : Taylor \& Francs Group.

Badan Pusat Statistik. (2018). Keadaan Angkatan Kerja di Indonesia Agustus 2018. Jakarta: BPS.

Badan Pusat Statistik. (2018). Perempuan dan Laki- Laki Indonesia 2018. Jakarta: BPS.

Cahya, Rizfanni Putri. (2015) Pemodelan Logit, Probit dan Complementary Log-Log pada Studi Kasus Partisipasi Perempuan dalam Pembangunan Ekonomi di Kalimantan Selatan. Surabaya: ITS.

Christi, Devima Mukti. (2013). Analisis Regresi Double Hurdle terhadap Faktor- Faktor yang Mempengaruhi Partsipasi Perempuan Kawin dalam Kegiatan Ekonomi di Jawa Timur. Surabaya: ITS. 
Ejaz, Menhak. (2010). Determinants of Female Labor Force Participation in Pakistan: An Instrumental Variable Approch [Tesis]. Labone: Lahore School of Economics.

Hosmer, D.W. \& Lemeshow, S. (2000). Applied Logistic Regression $2^{\text {nd }}$ edition. New York: John Wiley \& Sons, Inc.

Jati, Wasisto Raharjo. (2015). Bonus Demografi Sebagai Mesin Pertumbuhan Ekonomi : Jendela Peluang Atau Jendela Bencana Indonesia? (vol. 23, no.1). Yogyakarta: UGM : 1-19 Diakses dari situs https://jurnal.ugm.ac.id/populasi/article/view/8559/6591 pada tanggal 29 Oktober 2019

Suratiyah, K., Molo, M. \& Abdullah, I. (1996). Dilema Wanita antara Industri Rumah Tangga dan Aktvitas Domestik. Yogyakarta: Aditya Media. 